\title{
Effect of Moisture Content on Engineering Properties of Cashew Nut
}

\author{
R. Nath* and N. S. Chauhan \\ Department of Farm Machinery and Power Engineering, College of Agricultural Engineering \\ and Post-Harvest Technology (CAU, Imphal), Gangtok, Sikkim, India \\ *Corresponding author
}

\section{A B S T R A C T}

\section{Keyw ords \\ Cashew nut, Engineering properties, Moisture content}

\section{Article Info}

Accepted:

22 January 2021

Available Online:

10 February 2021
Cashew nut is an important cash crop having a fair share of the export market. In this study, the effect of moisture content on engineering properties of cashew nuts was evaluated to facilitate the design of agricultural machinery. The linear dimensions and geometric mean diameter are used in design of seed handling and cleaning machinery. The average sphericity, bulk density, true density, porosity, shell thickness and static coefficient of friction determines the design of sieve separators, storage, separation devices, drying equipment, width of shelling blades and selection of fabrication material for the hopper, respectively. The properties viz. length, width, thickness, geometric mean diameter, surface area, volume and sphericity increased in the range of 27.12 to $28.54 \mathrm{~mm}$, 21.27 to $22.59 \mathrm{~mm}, 15.06$ to $16.65 \mathrm{~mm}, 20.53$ to $22.04 \mathrm{~mm}, 1325.69$ to $1527.86 \mathrm{~mm}^{2}$ and 4695.41 to $5771.74 \mathrm{~mm}^{3}$ and 75.82 to $77.28 \%$, respectively with increase in moisture content. The true density was higher in comparison to the bulk density. The decrease in porosity and angle of repose was observed with increase in moisture content. The coefficient of static friction of the seed was found to be highest in case of plywood with an average shell thickness of $2.48 \mathrm{~mm}$.

\section{Introduction}

Cashew (Anacardium occidentale) is a tree fruit native to South and Central America. The tree produces seed commonly known as cashew nut. The kernel obtained from the cashew nut has a major contribution in the food industry and commonly consumed as snack in households. This seed comprises 40 to $57 \%$ oil and $21 \%$ protein (Ogunwolu et al., 2009). The seed is covered with hard shell and has versatile industrial applications including production of paints and lubricants. The Cashew Nut Shell Liquid (CNSL) excreted from the shell during the processing of cashew nut is a natural source of saturated and unsaturated long-chain phenol (Maia et al., 2012) which can be used as antioxidants. India was the second largest exporter of shelled cashew nut after Western Africa with an export of 1, 98,000 tonnes ( $\mathrm{t}$ ) in 2019 (Statistical Yearbook, 2019).

It had the largest area of 1062.04 ha under cashew and imports about 6 to 7 lakh t of raw cashew nuts annually. Cashew nut industry had observed an increase in $70 \%$ of international price in the recent times. India is 
a major cashew nut consuming country but a significant decline of ₹ 80 to 90 per $\mathrm{kg}$ in the price of raw cashew nut was observed due to depressed import duty on raw cashew nuts and higher cost of production (Cashew news, 2019).

Therefore, to mechanize the processes involved in production to consumption of the cashew nuts (includes design of sowing, harvesting, separation, roasting, shelling, peeling, grading, packaging and storage machinery) data about the engineering properties are required.

The basic dimensions of length, width and thickness are used in design of a cup for metering mechanism (Mohsenin, 1986) and seed handling machinery (Guiotto et al., 2013; Omobuwajo et al., 1999). The average sphericity of seed representing the same volume in a sphere (Omobuwajo et al., 1999) for design of sieve separators. The Geometric mean diameter indicates particle behavior in a pneumatic medium and ease of separating unwanted materials throughout the cleaning process (Guiotto et al., 2013), (Omobuwajo et al., 1999). The bulk density, true density and porosity are important for the design of hopper storage, separation devices and drying equipment, respectively. The shell thickness was used to determine the width of shelling blades. For constant flow of seeds and selection of fabrication material of the hopper the average static coefficient of friction is required (Olajide and Igbeka, 2003).

The angle of repose facilitates the filling of the flat storage facility where the seeds are peaked (Mohsenin, 1986; Heidarbeigi et al., 2009). Moisture content (mc) is an important factor considered in design and development of machineries for produce (Tabatabaeefar, 2003). The major objective was to study the effect of moisture content on various engineering properties of cashew nuts.

\section{Materials and Methods}

\section{Sample preparation}

Raw cashew nuts (Variety: Vengurla-4) were collected from the factories of Mancachar, Assam, India. The moisture content of the sample was determined by oven drying method, as per ASAE standard, 1993 (Ojediran et al., 2010; Seifi et al., 2010; Sezer et al., 2011). In oven drying method, the sample was kept in hot air oven at $105^{\circ} \mathrm{C}$ for 12 hours. The initial moisture content of the nuts was found to be14\%. The seed moisture content during the pre-shelling treatment using oven roasting method varied from 6 to $14 \%$. Therefore, four levels of moisture content $14,11,9$ and $6 \%(\mathrm{db})$ were selected for the analysis of the engineering properties. The seeds samples were conditioned by addition of calculated amount of distilled water in to achieve desired moisture content using equation (1) (Sologubik et al., 2013; Solomon and Zewdu, 2009; Sacilinket al., 2003; Karababa, 2006; Altuntas and Yildiz, 2007; Singh et al., 2010; Balasubramanian and Viswanathan, 2010). The seeds were refrigerated at $5{ }^{\circ} \mathrm{C}$ for five days to attain uniform moisture content. Prior to experimentation, the samples were kept in room temperature for $2 \mathrm{~h}$ (Balasubramanian and Viswanathan, 2010).

$Q=\frac{B i(M f-M i)}{M i+100}$

where, $B_{i}$ is initial mass of cashew nuts $(\mathrm{kg})$; $\mathrm{M}_{\mathrm{i}}$ and $\mathrm{M}_{\mathrm{f}}$ are the initial and final moisture content of cashew nuts in \% (db) and Q is the mass of water added $(\mathrm{kg})$.

\section{Properties determined}

The basic dimensions of 100 roasted cashew nuts along the principal axes viz. length 1 $(\mathrm{mm})$, width $\mathrm{w}(\mathrm{mm})$, and thickness $t(\mathrm{~mm})$ were measured using a digital Vernier caliper 
of $0.005 \mathrm{~mm}$ accuracy. The geometric mean diameter $\mathrm{G}(\mathrm{mm})$, surface area $\mathrm{A}\left(\mathrm{mm}^{2}\right)$, volume $(V)$, and sphericity $\mathrm{S}(\%)$ were determined using the following equation (2), (3) (4) and (5), respectively (Tabatabaeefar, 2003; Mohsenin, 1986; Singh et al., 2017) as shown below:

$$
\begin{aligned}
& G=(l w t)^{\frac{1}{3}} \\
& A=\pi(G)^{2} \\
& V=0.25\left(\frac{\pi}{6} \times l(w+t)^{2}\right) \\
& S=\frac{G}{L} \times 100 \%
\end{aligned}
$$

Thousand cashew nuts weight was measured by selecting 1000 nuts randomly and weighing it using an electronic balance of $0.001 \mathrm{~g}$ accuracy (Singh et al., 2017).

A digital weighing balance of $0.001 \mathrm{~g}$ accuracy was used to measure the individual weight of cashew nuts. True density $T$ $\left(\mathrm{kg} \mathrm{m}^{-3}\right)$ is defined as the ratio of the weight of individual cashew nut $\mathrm{M}(\mathrm{kg})$ to the volume of toluene displaced $\mathrm{V}\left(\mathrm{m}^{3}\right)$. The true density was evaluated using the toluene displacement method (Mohsenin, 1986; Dursun and Dursun, 2005; Singh et al., 2017) expressed as:

$T=\frac{M}{V}$

Equation 7 was used to determine the bulk density $\mathrm{B}\left(\mathrm{kg} \mathrm{m}^{-3}\right)$ where $\mathrm{m}$ and $\mathrm{v}$ are the total weight of cashew nuts $\mathrm{m}(\mathrm{kg})$ and the volume of cylinder $\mathrm{v}\left(\mathrm{m}^{3}\right)$ respectively(Chandrasekhar and Viswanathan, 1999; Singh et al., 2017).

$$
B=\frac{m}{v}
$$

The porosity $\mathrm{P}(\%)$ was calculated using the measured values of bulk density and true density by using the equation (8) (Mohsenin, 1986; Balasubramanian and Viswanathan,
2010; Singh et al., 2017)

$P=\frac{T-B}{T} \times 100 \%$

The angle of repose was evaluated using the emptying method by measuring the depth $\mathrm{d}$ $(\mathrm{mm})$ and height $\mathrm{h}(\mathrm{mm})$ of the heap formed naturally as a result of the gradual raising of the cylinder.

$\theta=\tan ^{-1}\left(\frac{2 h}{d}\right)$

The coefficients of static friction on four material surfaces mild steel $\left(\mu_{\mathrm{m}}\right)$, aluminum $\left(\mu_{\mathrm{a}}\right)$, galvanized iron $\left(\mu_{\mathrm{g}}\right)$ and plywood $\left(\mu_{\mathrm{p}}\right)$ was determined by using tilting table method (Fraser et al., 1978) calculated by equation (10) (Fig. 2) (Sahay and Singh, 2009; Khan, et al., 2017).

$\mu=\tan \emptyset$

The shell thickness $S_{\mathrm{T}}(\mathrm{mm})$ was measured using a digital micrometer of $0.01 \mathrm{~mm}$ accuracy at three points viz. top, middle and bottom of the cashew nut.

\section{Results and Discussion}

Engineering properties of cashew nuts were measured at moisture content level of $6,9,11$, $14 \%(\mathrm{db})$ within the moisture range of 6 to $14 \%(\mathrm{db})$.

\section{Length}

The length of cashew nuts [Fig. 1(a)] increased gradually from 27.12 to $28.54 \mathrm{~mm}$ as the moisture content increased from 6 to 14\% (db) (Fig. 3). Similar increasing trend was observed by Gharib-Zahedi et al., 2010, Seifi and Alimardani, 2010, and Sologubik, et al., 2013, for black cumin seeds, corn and barley seeds respectively.

Width 
The width of the cashew nuts [Fig. 1(b)] increased in the range of 21.27 to $22.59 \mathrm{~mm}$ with increase in moisture content as shown in Fig. 4. Similar increasing trend was observed for black cumin seeds (Gharib-Zahedi et al., 2010) and corn (Seifi and Alimardani, 2010).

\section{Thickness}

The thickness of the cashew nuts [Fig. 1(c)] was found to have increased with increase in moisture content. With increase in moisture content from 6 to $14 \%$ (db) the seed thickness increased from 15.06 to $16.65 \mathrm{~mm}$ as shown in Fig. 5. Similar increasing trend was observed for black cumin seed (Gharib-Zahedi et al.,
2010), corn (Seifi and Alimardani, 2010) and barley seeds (Sologubik, et al., 2013).

\section{Geometric mean diameter}

The geometric mean diameter was calculated by using the linear dimensions as specified in equation 2 . The geometric mean diameter was observed to be increasing linearly from 6$11 \% \mathrm{mc}$ but increased gradually thereafter (Fig. 6). Similar increasing trend was observed by Shafiee et al., (2009) for dragon's head seeds, Singh et al., (2010) for millet and Sologubik, et al., (2013) for barley seeds.

Fig.1 Basic dimensions of cashew nut (a) Length (L), (b) Width (W), (c) Thickness (T)

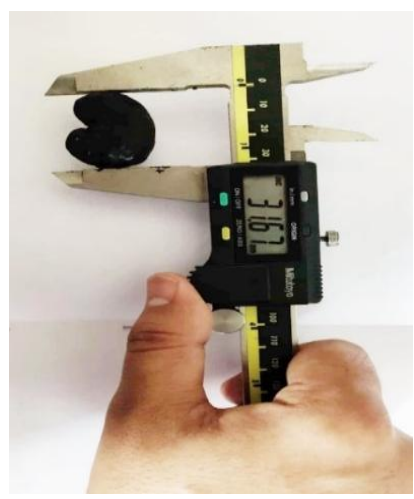

(a)

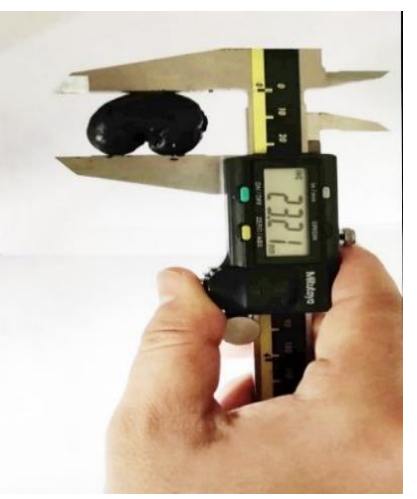

(b)

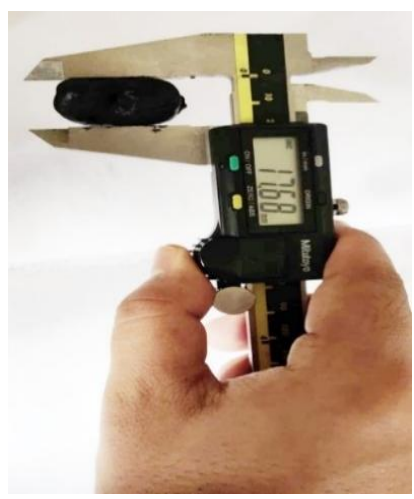

(c)

Fig.2 Tilting-top table apparatus for measurement of coefficient of static friction

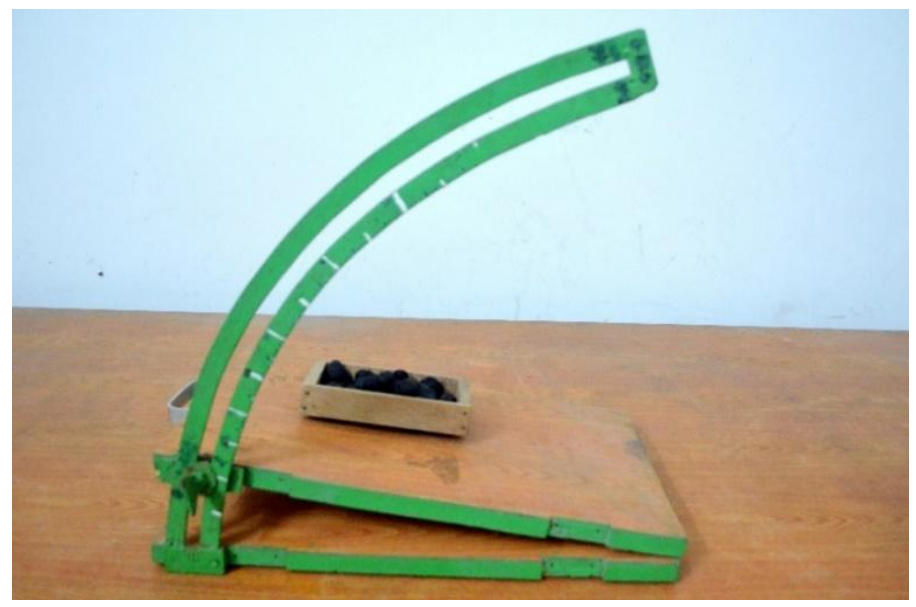


Fig.3 Effect of moisture content on length of the cashew nut

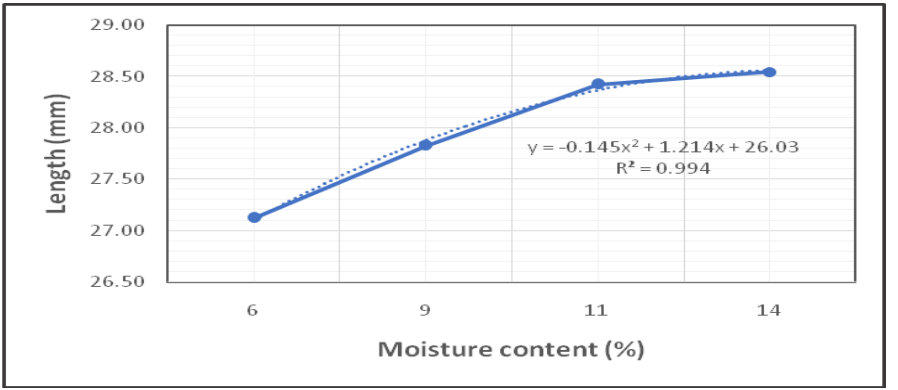

Fig.4 Effect of moisture content on width of the cashew nut

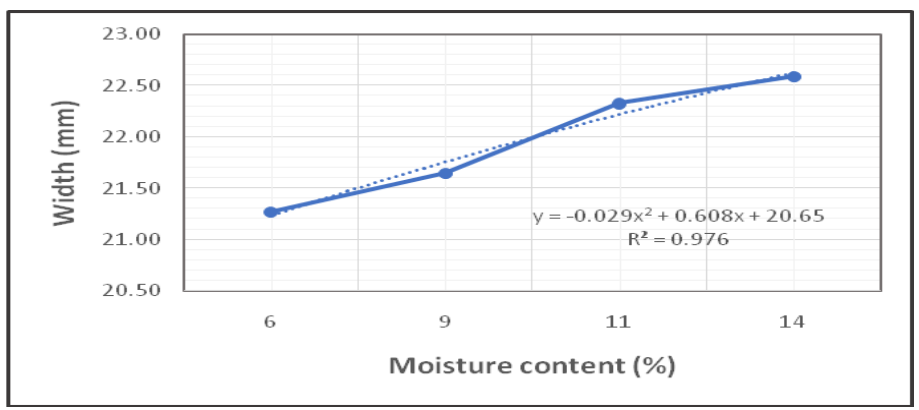

Fig.5 Effect of moisture content on thickness of the cashew nut

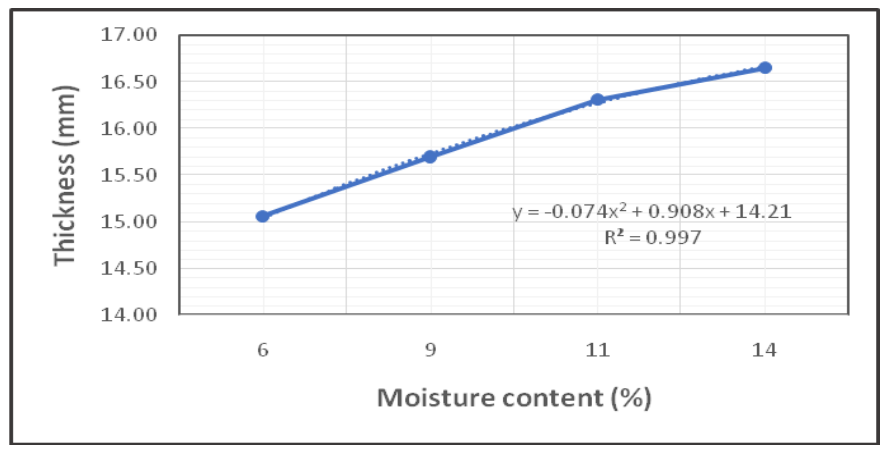

Fig.6 Effect of moisture content on geometric mean diameter of the cashew nut

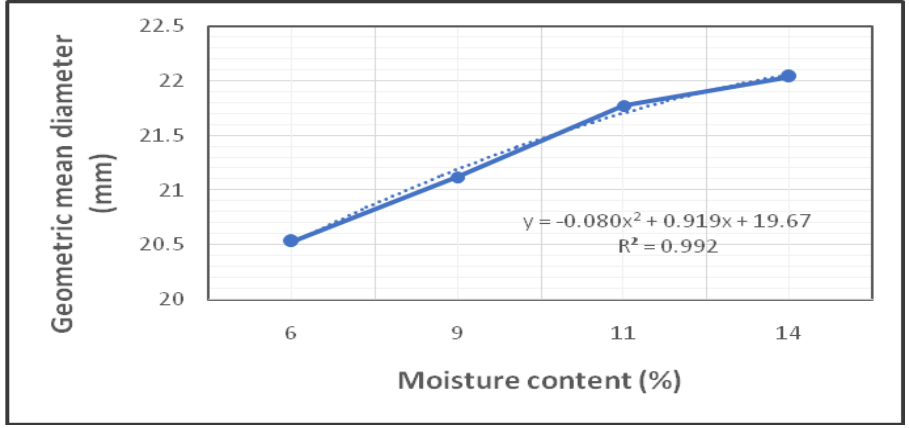


Fig.7 Effect of moisture content on surface area of the cashew nut

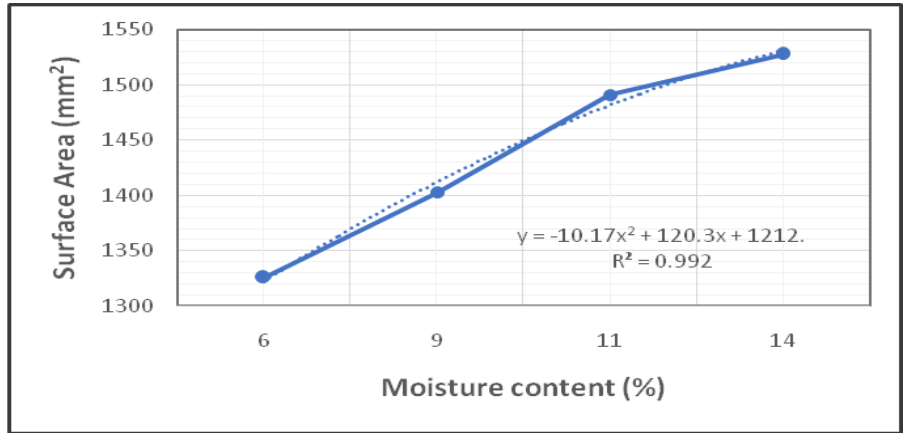

Fig.8 Effect of moisture content on volume of the cashew nut

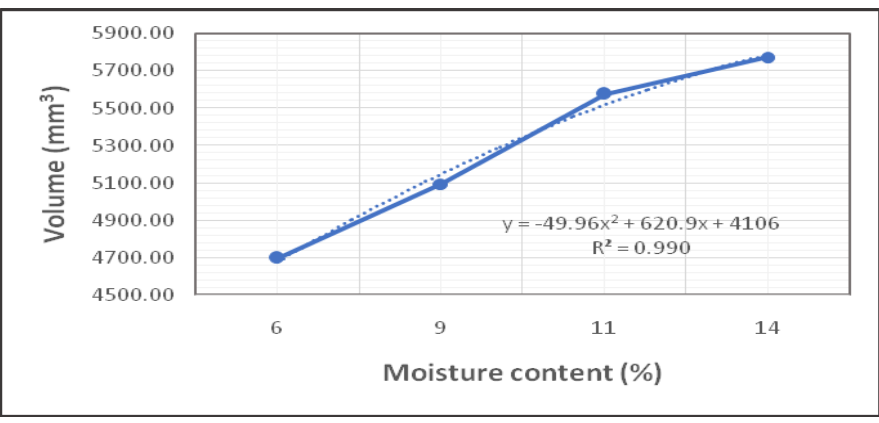

Fig.9 Effect of moisture content on sphericity of the cashew nut

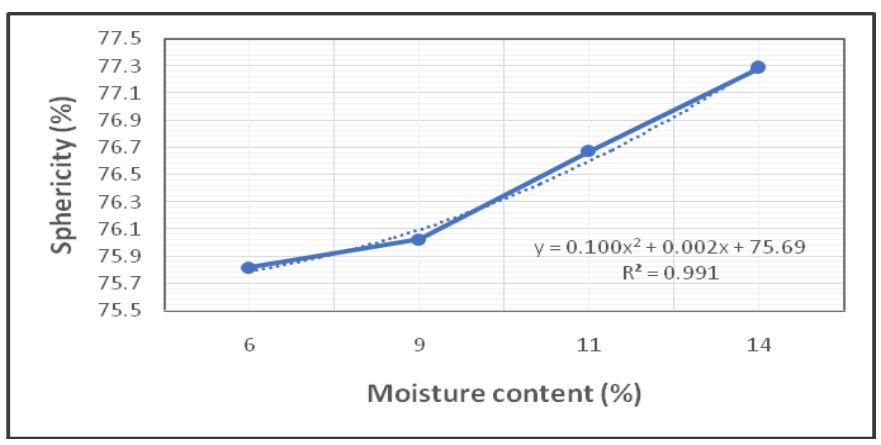

Fig.10 Effect of moisture content on thousand cashew nuts weight

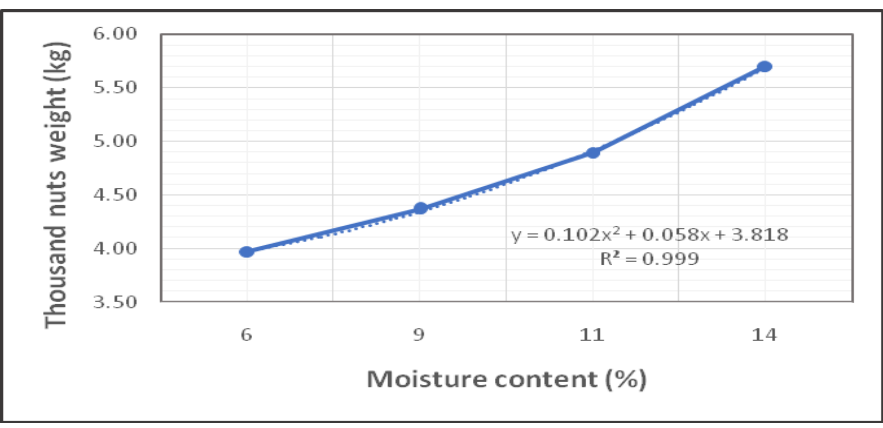


Fig.11 Effect of moisture content on true density of the cashew nut

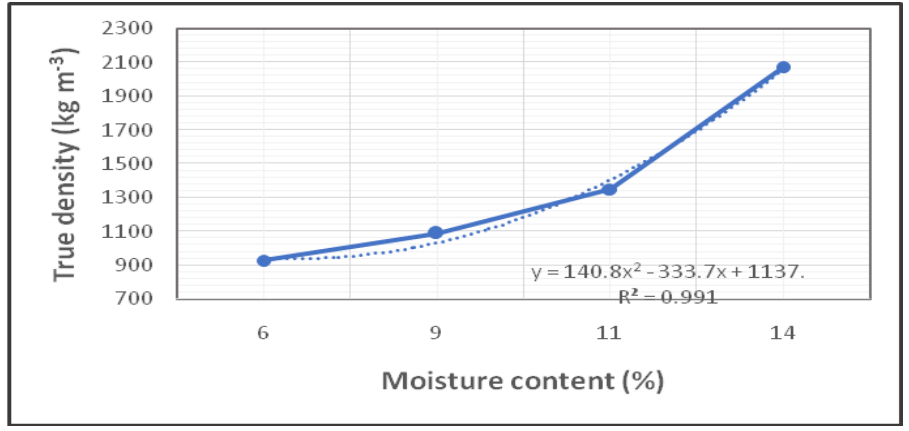

Fig.12 Effect of moisture content on bulk density of the cashew nut

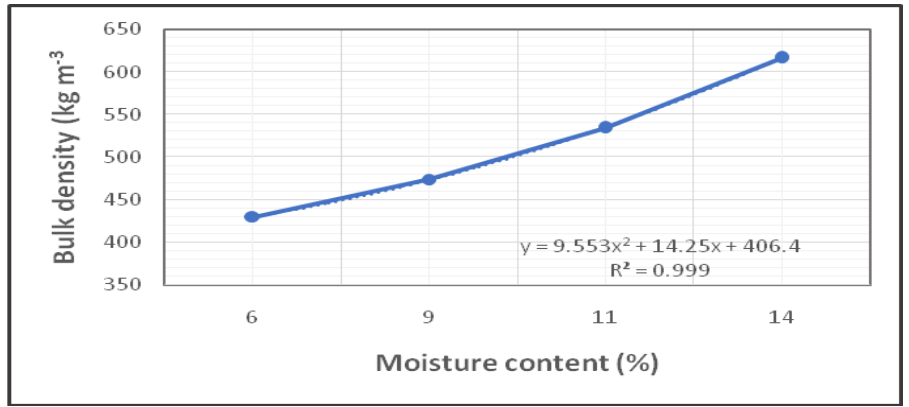

Fig.13 Effect of moisture content on porosity of the cashew nut

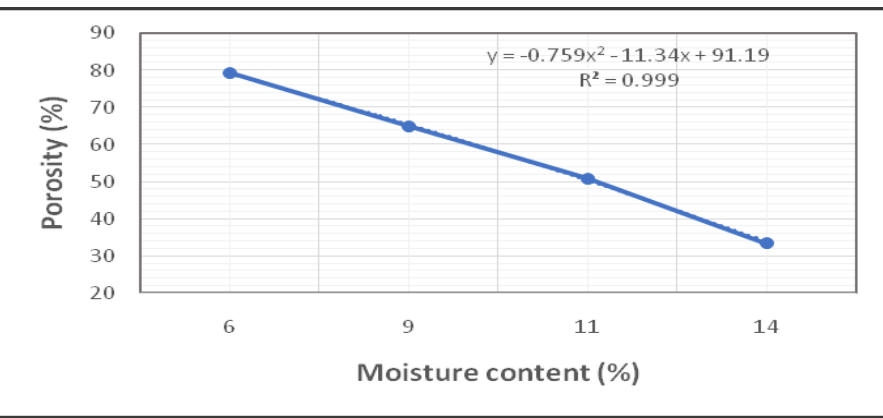

Fig.14 Effect of moisture content on angle of repose of the cashew nut

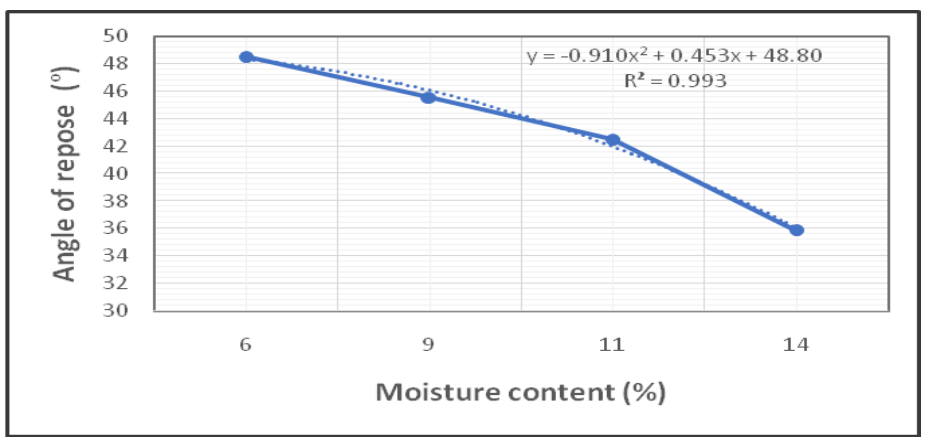


Fig.15 Effect of moisture content on coefficient of static friction of the cashew nut

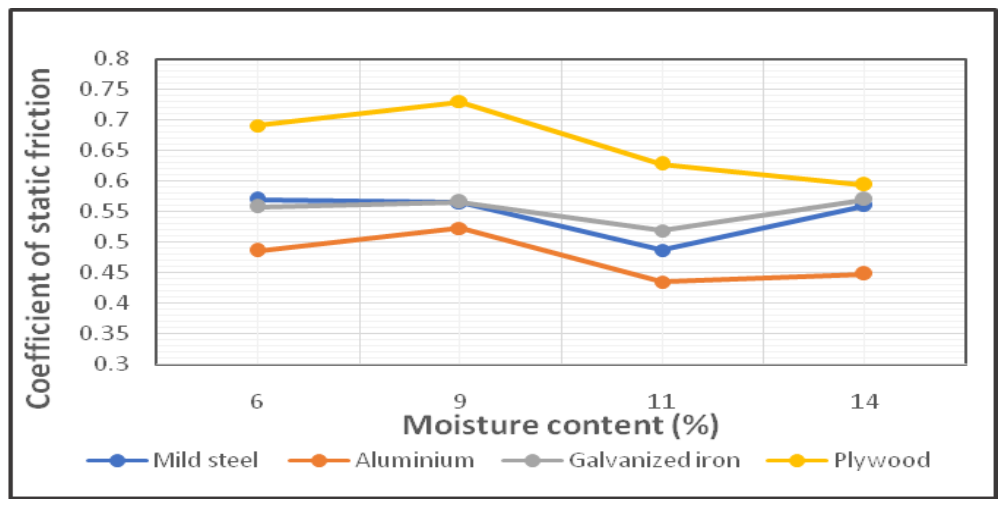

\section{Surface area}

The surface area was calculated by using the linear dimensions as specified in equation 3. The surface area was observed to be increasing linearly from $6-11 \% \mathrm{mc}$ but increased steadily thereafter (Fig. 7). Similar increasing trend was observed by Shafiee $e t$ al., 2009 for dragon's head seeds, Singh et al., 2010 for millet and Sologubik, et al., 2013 for barley seeds.

\section{Volume}

The volume of cashew nuts was calculated by using equation 4 . The volume was observed to be increasing linearly from $6-11 \% \mathrm{mc}$ but increased steadily thereafter (Fig. 8). Similar increasing trend was observed by Singh, et al., 2017, for finger millet.

\section{Sphericity}

The sphericity was calculated by using geometric mean diameter and the length of the seeds (equation 5). The sphericity increased gradually from 75.82 to $77.28 \%$ with increase in moisture content from 6 to 14\% (db) (Fig. 9). Similar trend was observed by Shafiee et al., 2009 for dragon's head seeds, Singh et al., 2010 for millet, Sologubik, et al., 2013 for barley seeds and Singh, et al., 2017 for finger millet.

\section{Thousand cashew nuts weight}

The thousand cashew nuts weight $\left(\mathrm{W}_{1000}\right)$ was determined for the concerned levels of moisture content as shown in Fig. 10. The thousand seed weight increased within the range of 3.97 to $5.70 \mathrm{~kg}$ with increase in moisture content from 6 to $14 \%$ (db). Similar increase in seed weight was observed by Shafiee et al., (2009) for dragon's head seeds and Singh, et al., (2017) for finger millet.

\section{True density}

The true density trend to increase with increase of moisture content. The true density varied within the range of 926.83 to 2075.00 $\mathrm{kg} \mathrm{m}^{-3}$ with moisture content ranging from 6 to $14 \%$ (db) (Fig. 11). Since, true density is directly proportional to mass, this explains the increase in moisture content increased the mass of the cashew nuts. Shafiee et al., 2009, Singh et al., 2010 and Singh, et al., 2017 reported similar results for dragon's head seed, barnyard millet and finger millet respectively.

\section{Bulk density}

The bulk density trend to increase with increase of moisture content. The bulk density varied within the range 429.96 to $616.55 \mathrm{~kg}$ $\mathrm{m}^{-3}$ with moisture content ranging from 6 to 
14\% (db) (Fig. 12). Similar linear trend was reported by Aviara et al., 1999 for guna seeds.

\section{Porosity}

The porosity trend to decrease with increase of moisture content from 6-14\% (db). The porosity varied from 79.28 to $33.48 \%$ with moisture content ranging from 6 to $14 \%$ (db) (Fig. 13). The decrease in porosity occurs as the individual volume of the seed increases due to the absorption of moisture. Similar behavior was reported by Mwithiga and Sifuna, 2006 for sorghum seeds.

\section{Angle of repose}

The angle of repose decreased significantly from $35.87^{\circ}$ to $48.51^{\circ}$ with increase in moisture content from 6 to $14 \%$ (db) (Fig. 14). This is because seed surface smoothens at higher moisture content in comparison to dry seeds. Similar behavior was reported by Mwithiga and Sifuna, 2006 for sorghum seeds.

\section{Coefficients of static friction}

The coefficient of static friction of casher nuts was determined by using four surfaces (Fig. 2) (mild steel, aluminium, galvanized iron and plywood) at 6, 9, 11, and $14 \%$ moisture content (Fig. 15). The coefficient of static friction for mild steel, aluminium, galvanized iron and plywood was in the range of 0.49 to $0.57,0.44$ to $0.52,0.52$ to $0.57,0.59$ to 0.73 , respectively.

\section{Shell thickness}

The shell thickness of the cashew nut was found to be in the range of 1.97 to $3.12 \mathrm{~mm}$ with an average value of $2.48 \mathrm{~mm}$. The shell thickness remains the same in contrast to variation in moisture content.
In conclusion it is evident from the results of the study that most of the parameter values (i.e., length, width thickness, GMD, surface area, volume, sphericity, $\mathrm{W}_{1000}$, true density and bulk density) increased with increase in moisture content from $6 \%$ to $14 \%$. However, the values of porosity and angle of repose decreased with increase in moisture content in the same range. No specific trend was noticed for the coefficient of static friction. The results would be helpful in designing various components of machines for post-harvest processing of cashew nut.

\section{References}

Altuntaş, E., and Y1ldiz, M. 2007. Effect of moisture content on some physical and mechanical properties of faba bean (Vicia faba L.) grains. Journal of Food engineering, 78(1), 174-183.

Aviara, N. A., Gwandzang, M. I., and Haque, M. A. 1999. Physical properties of guna seeds. Journal of Agricultural Engineering Research, 73(2), 105-111.

Balasubramanian, S., and Viswanathan, R. 2010. Influence of moisture content on physical properties of minor millets. Journal of food science and technology, 47(3), 279-284.

Cashew news. 2019. ICAR-Directorate of cashew research. https://cashew.icar.gov.in/wpcontent/uploads/2019/08/CN-Jan-Jun2019.pdf. Accessed 16th December, 2020.

Chandrasekar, V., and Viswanathan, R. 1999. Physical and thermal properties of coffee. Journal of agricultural engineering research, 73(3), 227-234.

Dursun, E., and Dursun, I. 2005. Some physical properties of caper seed. Biosystems Engineering, 92(2), 237245.

Gharib-Zahedi, S. M. T., S. M. Mousavi, A. Moayedi, A. T. Garavand and S. M. 
Alizadeh. 2010. Moisture dependent engineering properties of black cumin (Nigella sativa L.) seed. Agricultural Engineering International: the CIGR journal. Manuscript 1437. Vol. XII. March.

Guiotto, E. N., Ixtaina, V. Y., Tomás, M. C. M., and Nolasco, S. M. 2013. Moisturedependent engineering properties of chia (Salvia hispánica L.) seeds. Food Industry, 381-397.

Heidarbeigi, K., Ahmadi, H., Kheiralipour, K., and Tabatabaeefar, A. 2009. Some physical and mechanical properties of khinjuk. Pakistan Journal of Nutrition, 8(1), 74-77.

Karababa, E. 2006. Physical properties of popcorn kernels. Journal of Food Engineering, 72(1), 100-107.

Khan, K., Moses, S. C., Kumar, A., and Soni, S. 2017. Design a seed metering wheel for sowing corn (Zea mays) seeds. Plant Archives, 17(2), 1651-1657.

Maia, F. J., Clemente, C. D. S., Oliveira, T. M., Lomonaco, D., Oliveira, T. I., Almeida, M. O., and Mazzeto, S. E. 2012. Electrochemical and computational studies of phenolic antioxidants from cashew nut shell liquid. Electrochimica Acta, 79, 67-73.

Mohsenin, N.N. 1986. Physical Properties of Plant and Animal Materials, 1st edn. New York, Gordon and Breach Science Publishers, pp. 1-891.

Mwithiga, G., and Sifuna, M. M. 2006. Effect of moisture content on the physical properties of three varieties of sorghum seeds. Journal of food engineering, 75(4), 480-486.

Ogunwolu, S. O., Henshaw, F. O., Mock, H. P., Santros, A., and Awonorin, S. O. 2009. Functional properties of protein concentrates and isolates produced from cashew (Anacardium occidentale L.) nut. Food chemistry, 115(3), 852-858.

Ojediran, J. O., Adamu, M. A., and Jim-
George, D. L. 2010. Some physical properties of Pearl millet (Pennisetum glaucum) seeds as a function of moisture content. African Journal of General Agriculture, 6(1), 39-46.

Olajide, J. O., and Igbeka, J. C. 2003. Some physical properties of groundnut kernels. Journal of Food Engineering, 58(2), 201-204.

Omobuwajo, T. O., Akande, E. A., and Sanni, L. A. 1999. Selected physical, mechanical and aerodynamic properties of African breadfruit (Treculia africana) seeds. Journal of Food Engineering, 40(4), 241-244.

Sacilik, K., Öztürk, R., and Keskin, R. 2003. Some physical properties of hemp seed. Biosystems engineering, 86(2), 191198.

Sahay, K.M. and Singh, K.K. 2009. Unit operations of agricultural processing. 2nd edition. Vikas publishing house pvt.ltd., New Delhi, pp.10-13.

Seifi, M. R., and Alimardani, R. 2010. The moisture content effect on some physical and mechanical properties of corn (Sc 704). Journal of Agricultural Science, 2(4), 125.

Sezer, I., Balkaya, A., Karaağaç, O., and Öner, F. 2011. Moisture dependent of some physical and morphological properties of dent corn (Zea mays var. indentzto Sturt) seeds. African Journal of Biotechnology, 10(15), 2857-2866.

Shafiee, S., A. Modares Motlagh, S. Minaee and K. Haidarbigi. 2009. Moisture dependent physical properties of dragon's head seeds (Lallemantia iberica). Agricultural Engineering International: the CIGR Ejournal. Manuscript 1192. Vol. XI. June.

Singh, K. P., Mishra, H. N., and Saha, S. 2010. Moisture-dependent properties of barnyard millet grain and kernel. Journal of Food Engineering, 96(4), 598-606. 
Singh, K. P., Potdar, R. R., Agrawal, K. N., Tiwari, P. S., and Hota, S. 2017. Effect of Moisture Content on Physical Properties of Finger (Eleusine coracana) Millet. AMA, Agricultural Mechanization in Asia, Africa and Latin America, 48(4), 24-32.

Sologubik, C. A., Campañone, L. A., Pagano, A. M., and Gely, M. C. 2013. Effect of moisture content on some physical properties of barley. Industrial Crops and Products, 43, 762-767.

Solomon, W. K., and Zewdu, A. D. 2009.
Moisture-dependent physical properties of Niger (Guizotia abyssinica Cass.) seed. Industrial crops and products, 29(1), 165-170.

Statistical yearbook. 2019. INC International Nut and dried fruit. https://www.nutfruit.org/files/tech/1553 5

21370_INC_Statistical_Yearbook_2018 .pdf. Accessed 16th December,2020.

Tabatabaeefar, A. 2003. Moisture dependent physical properties of wheat. International Agrophysics, 17(4).

\section{How to cite this article:}

Nath, R. and Chauhan, N. S. 2021. Effect of Moisture Content on Engineering Properties of Cashew Nut. Int.J.Curr.Microbiol.App.Sci. 10(02): 3042-3052.

doi: https://doi.org/10.20546/ijcmas.2021.1002.333 